Western Washington University

Western CEDAR

6-2010

\title{
Mitochondrial DNA Diversity in Mennonite Communities from the Midwestern United States
}

Phillip Edward Melton

Centre for Genetic Origins of Health and Disease

M.J. Mosher

Western Washington University, m.j.mosher@wwu.edu

Rohina C. Rubicz

Texas Biomedical Research Institute

Mark Zlojutro

Texas Biomedical Research Institute

Michael H. Crawford

University of Kansas

Follow this and additional works at: https://cedar.wwu.edu/anthropology_facpubs

Part of the Biological and Physical Anthropology Commons

\section{Recommended Citation}

2010 Melton PE, Mosher MJ, Rubicz R, Zlojutro M, Crawford M. Mitochondrial DNA diversity in Mennonite communities from the Midwestern United States. Hum Biol 82(3):267-289.

This Article is brought to you for free and open access by the Anthropology at Western CEDAR. It has been accepted for inclusion in Anthropology Faculty and Staff Publications by an authorized administrator of Western CEDAR. For more information, please contact westerncedar@wwu.edu. 
Mitochondrial DNA Diversity in Mennonite Communities from the Midwestern United States

Author(s): PHILliP E. MELTON, M. J. MOSHER, R. RUBICZ, M. ZLOJUTRO and M. H. CRAWFORD

Source: Human Biology, Vol. 82, No. 3 (June 2010), pp. 267-289

Published by: Wayne State University Press

Stable URL: https://www.jstor.org/stable/41466678

Accessed: 28-02-2019 20:44 UTC

\section{REFERENCES}

Linked references are available on JSTOR for this article:

https://www.jstor.org/stable/41466678?seq=1\&cid=pdf-reference\#references_tab_contents You may need to $\log$ in to JSTOR to access the linked references.

JSTOR is a not-for-profit service that helps scholars, researchers, and students discover, use, and build upon a wide range of content in a trusted digital archive. We use information technology and tools to increase productivity and facilitate new forms of scholarship. For more information about JSTOR, please contact support@jstor.org

Your use of the JSTOR archive indicates your acceptance of the Terms \& Conditions of Use, available at https://about.jstor.org/terms

Wayne State University Press is collaborating with JSTOR to digitize, preserve and extend access to Human Biology 


\title{
Mitochondrial DNA Diversity in Mennonite Communities from the Midwestern United States
}

\author{
PHILliP E. MELTON, ${ }^{1}$ M. J. MOSHER, ${ }^{2}$ R. RUBICZ, ${ }^{1}$ M. ZLOJUTRO,
} AND M. H. CRAWFORD ${ }^{2}$

\begin{abstract}
We examined mitochondrial DNA (mtDNA) variation in six Mennonite communities from Kansas (Goessel, Lone Tree, Garden View, Meridian, and Garden City) and Nebraska (Henderson) to determine their genetic structure and its relationship to population history. Mitochondrial DNA haplogroup and haplotype information were obtained from blood samples from 118 individuals. Molecular genetic variation was analyzed using diversity measures, neutrality test statistics, spatial analysis of molecular variance (SAMOVA), and multidimensional scaling plots. The Mennonite samples exhibited eight western European mtDNA haplogroups: H, HVO, I, J, K, T, U, and X. Comparable to other populations of European descent, haplogroup $\mathrm{H}$ was the most frequent in all six communities and ranged from $35 \%$ in Lone Tree to $75 \%$ in Old Order Mennonites from Garden City. Fifty-eight different mtDNA haplotypes were found in these groups with only one shared among all six populations. Haplotype diversities varied from 0.81 in Goessel to 0.96 in Henderson and Garden View. Multivariate statistical analysis of these populations indicates that these Anabaptist communities formed new congregations by fissioning along familial lines. Population subdivision of these communities into congregations supports previously documented patterns of fission-fusion. These haploid molecular data provide a more accurate reflection of biological relationships between midwestern Mennonite communities than evidence based on classical genetic markers.
\end{abstract}

Mitochondrial DNA (mtDNA) has been used extensively to investigate the genetic structure of worldwide indigenous populations and to reconstruct the complexities of human evolutionary history (Achilli et al. 2008; Behar et al. 2008; Finnilä et al. 2001; Herrnstadt et al. 2002; Macaulay et al. 1999; Torroni and Wallace 1994). However, despite the successful application of mtDNA variation to anthropological genetics, little mtDNA research has been conducted to date on the Anabaptist diaspora (Pichler et al. 2010; van der Walt et al. 2005). Populations belonging to the Anabaptist movement (Amish, Hutterites, and Mennonites) have

'Department of Genetics, Southwest Foundation for Biomedical Research, San Antonio, TX.
${ }^{2}$ Laboratory of Biological Anthropology, Department of Anthropology, University of Kansas, Lawrence, KS.

Human Biology, June 2010, v. 82, no. 3, pp. 267-289.

Copyright $\odot 2010$ Wayne State University Press, Detroit, Michigan 48201-1309

KEY WORDS: ANABAPTIST, MENNONITES, KANSAS, NEBRASKA, MITOCHONDRIAL DNA, MTDNA HAPLOGROUPS, HAPLOTYPE DIVERSITY, GENETIC STRUCTURE, POPULATION HISTORY, FISSION-FUSION. 
experienced dynamic histories characterized by several migratory events, which have contributed to their unique genetic structure (Caliskan et al. 2008; Crawford 2000a, 2000b; Crawford et al. 1989; Martin et al. 1996).

The Anabaptist movement began shortly after the Reformation and can be divided into three major religious denominations: (1) Mennonites, a group that originated in northern Europe and the Netherlands and were followers of Menno Simons; (2) Hutterites, a group that began in Austria and followed the teachings of Jacob Hutter; and (3) Amish, a group that formed in Switzerland and southern Germany and followed Jacob Amman. Each of these groups went through a number of persecutions and demographic events that led to population movement in Europe and eventual emigration to the Americas (L. Rogers and Rogers 2000; Stevenson and Everson 2000). Traditionally, studies of these religious isolates have focused on unique genetic disorders because of founder effects, isolation from the outside world, distinctive lifestyles, and detailed genealogical information that these populations maintain (Crawford 2000a). This information may also be important for understanding the genetic history and population structure of modern European American populations because several of these groups migrated and settled in the Americas in the 1800s.

The Reformation was a religious movement initiated in 1517 when Martin Luther nailed his Ninety Five Theses to the door of the local Catholic church in present-day Wittenburg, Germany (MacCulloch 2003). This movement was an attempt to reform corruption within the Catholic Church. A number of western European Catholics were concerned with false doctrines and practices from within the church. These practices included the selling of indulgences, the forgiveness of sins, and simony, the practice of buying and selling church positions. Subsequent arguments regarding the interpretation of doctrine and spiritual disagreements between the leaders of the Reformation caused the movement to split into different Protestant denominations. The most important of these denominations included the Lutherans, Calvinists, Presbyterians, and the Anabaptists (MacCulloch 2003).

Shortly after the Reformation began, some religious groups came to be identified as Anabaptist. The belief in adult baptism was primarily held by a number of religious factions that arose in Switzerland, Germany, and the Netherlands around 1525 (L. Rogers and Rogers 2000). These groups represented the far left of the Reformation movement and believed in the separation of church and state, adult baptism, and pacifism. Following a series of small-scale rebellions, local authorities began to view Anabaptists as a threat to social order. Persecution of these groups became severe. This persecution resulted in the emigration of these populations to the underdeveloped agricultural regions of eastern Europe and eventually to the Americas. The three major Anabaptist, or Brethren as they refer to themselves, denominations were never a unified movement and survive today as the Amish, Hutterites, and Mennonites (L. Rogers and Rogers 2000). These groups have different cultural histories that may be reflected in their genetic structure, and these events are revealing because these ethnohistoric events can be assessed in terms of their biological impact. 
Dutch and German Mennonite refugees immigrated to Polish-controlled areas around Danzig (Gdansk), and in 1699 eighteen families formed the Przechówko church. This population increased in size and maintained meticulous genealogical records. In 1821, all but seven families of the congregation moved to Russia and settled in the Ukraine near the Molotschna River. This congregation then adopted the name Alexanderwohl, in honor of the Russian czar. Subsequent changes in economic conditions, changes in Russian governmental policies concerning military exemptions, and internal subdivisions of these groups caused the Alexanderwohl Mennonites to move to the United States in 1874 (L. Rogers and Rogers 2000). Upon arrival in the United States the group split into two separate divisions. One group settled west of Lincoln, Nebraska, near present-day Henderson. The other group settled in Kansas, 40 mi north of Wichita. Another Kansas Mennonite community is representative of the Church of God in Christ Mennonites. This congregation was founded in 1858 by John Halderman in Ohio and is considered a heterogeneous group composed of Pennsylvanian Dutch and Germans mixed with large Mennonite immigrant populations from southern Russia (Crawford et al. 1989). The Halderman Mennonite community split into the congregations in Meridian, Garden View, and Lone Tree. The most recent Mennonite immigrants to Kansas are the Old Colony Mennonites, who reside near Garden City. This community traces its history to a group of Mennonites who immigrated to western Canada in the 1870s. In the 1920s approximately 6,000 individuals moved to Cuauhtemoc, Chihuahua, in Mexico where they formed 15 colonies (Allen 1988; Allen and Redekop 1967, 1987). In the late 1990s, a small number of these individuals migrated to southwest Kansas.

In the present study, we measure mtDNA diversity within and between distinct congregations from midwestern Mennonite communities and assess their biological relationship with other European populations. Previous research on classical genetic blood polymorphisms and immunoglobulin haplotype frequencies in these particular communities has demonstrated that a fission-fusion pattern for recent evolutionary history best explains their genetic history and that new congregations fissioned along familial lines (Crawford 2005; Crawford et al. 1989; Demarchi et al. 2005; Martin et al. 1996). Our aims in this article are to (1) determine the maternal genetic relationship between the six Mennonite communities using mtDNA, (2) investigate the maternal biological relationship among three different congregations of Mennonites and other Anabaptist and European populations, and (3) establish whether population subdivision within the congregations demonstrates patterns of fission-fusion as previously reported for classical genetic markers and autosomal genetic data.

\section{Materials and Methods}

Population Samples. The Mennonite communities of Kansas and Nebraska are divided into three religious congregations: (1) Alexanderwohl, which includes the communities of Goessel, Kansas, and Henderson, Nebraska; (2) Halderman, 


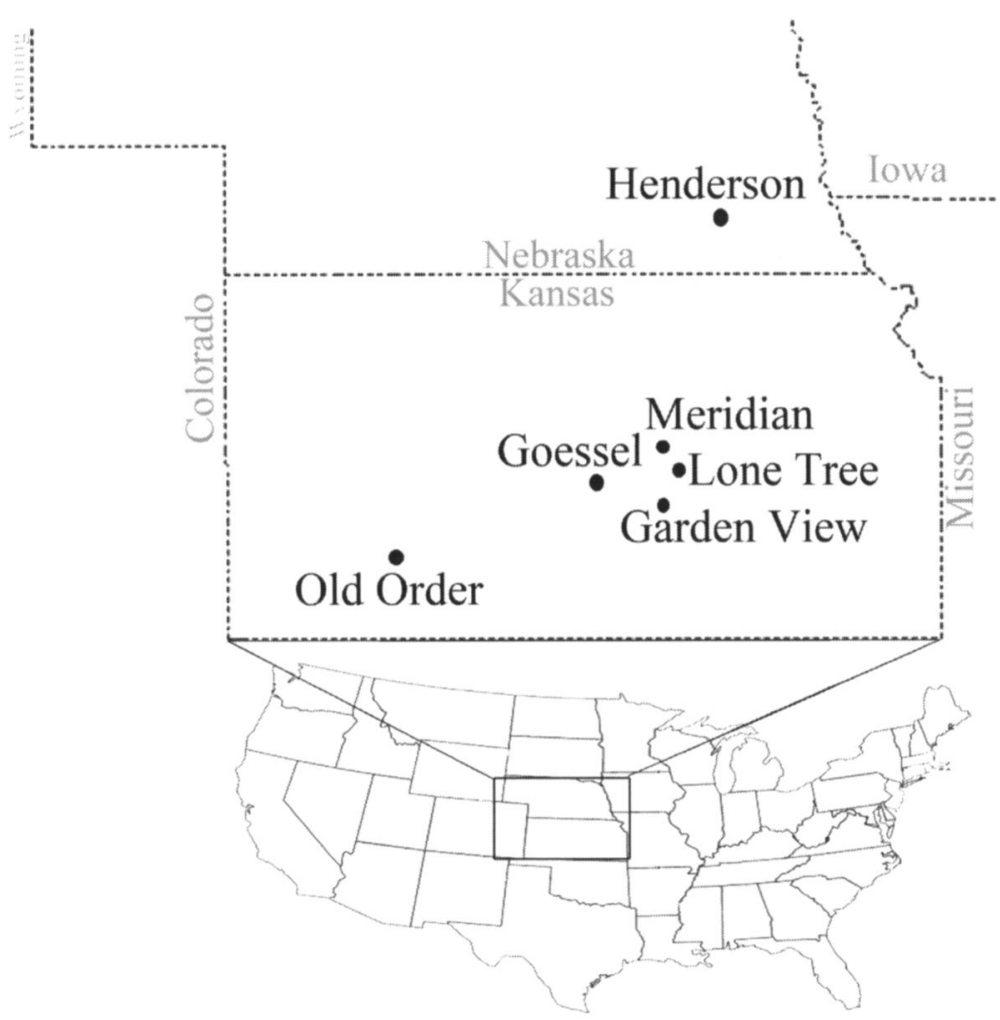

Figure 1. Geographic locations of Mennonite communities in Kansas and Nebraska.

which includes the Kansas communities of Meridian, Lone Tree, and Garden View; and (3) Old Order Mennonites, originally from Cuauhtemoc, Chihuahua, Mexico, but more recently relocated near Garden City, Kansas. This study included 118 individuals, with samples collected as part of a long-term multidisciplinary study of midwestern Mennonite communities in the United States (Figure 1). Kansas samples were collected by researchers from the Laboratory of Biological Anthropology, University of Kansas, in 2004, as described previously (Demarchi et al. 2005). Henderson samples were collected in 1981 as part of a study of biological aging (Crawford 2000a).

The Kansas blood samples were collected by venipuncture from fasting adult individuals after informed consent was obtained. Samples were centrifuged, and plasma was separated on site. Samples used in this analysis included 22 individuals from Goessel, 19 from Henderson, 18 from Meridian, 23 from Lone Tree, 20 from Garden View, and 16 Old Order Mennonites. These samples were stored at $-80^{\circ} \mathrm{C}$ until extraction. To avoid close relatives, we used married couples in these analyses and double-checked against pedigrees to ensure accuracy. Comparative 
mtDNA haplogroup and HVS-I data for three Anabaptist populations (Amish, Hutterites, and Swiss Anabaptist) and seven European groups (Dutch, Germans, Polish, Prussian, Russians, Swiss, and Ukrainians) were collected from the literature and publicly accessible databases (http://www.familytreedna.com/projects. aspx; see Table 1 for references and urls). The Swiss Anabaptist population is a collection of European Mennonite and North American individuals descended from the Swiss Brethren, a Mennonite congregation.

DNA Extraction and mtDNA Analysis. DNA was extracted from blood sample buffy coats using a Super Quik-Gene Kit (University of Kansas, Lawrence). All samples were characterized for the 10 European restriction length fragment polymorphism (RFLP) haplogroups ( H, I, J, K, N, R, T, U, V, and X) using polymerase chain reaction (PCR) and associated restriction site enzymes. Primer pairs and amplification conditions used in this study have been previously described by Torroni et al. (1996). Restriction fragments were visualized with ultraviolet light on 3\% NuSieve agarose gels (FMC Bioproducts, Rockland, Maine) and recorded as present or absent. HVS-I sequences were generated on an ABI 370 capillary system sequencer through automated fluorescence using the ABI 3.0 Big Dye sequencing cycle kit (Applied Biosystems, Foster City, California) and primers $15976 \mathrm{~F}$ and 16422R (Integrated DNA Technologies, Coralville, Iowa). All sequencing was performed at the University of Kansas Natural History Museum DNA Sequencing Laboratory. Sequences were aligned and compared with the revised human mtDNA Cambridge Reference Sequence (Anderson et al. 1981; Andrews et al. 1999) using the BioEdit sequence alignment editor (Hall 1999). Sequences were characterized between mtDNA HVS-I base pairs 16000 and 16399.

\section{Analytical Techniques}

Intrapopulational Analysis. Mitochondrial DNA HVS-I sequence data for all study and comparative populations were estimated for nucleotide $(\pi)$ and haplotype $(h)$ diversity using Nei's (1987) methods. These diversity indexes indicate whether a population has been affected by genetic drift for a neutral genetic system by estimating the probability that two randomly chosen haplotypes in a sample will be different (Saitou and Nei 1987). Two neutrality test statistics, Tajima's $D$ (Tajima 1989) and Fu's $F_{s}$ (Fu 1997), were used to distinguish population growth from constant population size. Tajima's $D$ is considered a more conservative test than Fu's $F_{s}$ and is less sensitive to large population expansions (Ramos-Onsins and Rozas 2002). Demographic expansion is expressed as a negative value, whereas positive numbers indicate either genetic drift or natural selection. Statistically significant values were generated through random samples under the assumption of selective neutrality and population equilibrium using the coalescent simulation model (Hudson 1990). Distributions of pairwise differences (i.e., mismatch distributions) within Mennonite communities and congregations were 


\section{2 / MELTON ET AL.}

plotted; the modalities reflect demographic history and genetic structure (A. R. Rogers and Harpending 1992; A. R. Rogers et al. 1996). All measures were calculated using the Arlequin 3.11 computer package (Excoffier et al. 2005).

Phylogenetic Analysis. A phylogenetic network using the median-joining method was constructed to determine the genetic relationship between haplotypes found within the six Mennonite study communities (Bandelt et al. 1995, 1999). Median-joining networks offer an advantage over genetic trees because they distinguish between resolvable and irresolvable character conflicts that occur as a result of homoplasy. These reticulations can be interpreted as recombination, sequence errors, or "phantom mutations." Median-joining networks were computed and visualized with the program Network 4.51 (http://www.fluxus-engineering. com) and incorporated into current human mtDNA phylogeny (van Oven and Kayser 2009).

Interpopulational Analysis. Nonmetric multidimensional scaling (MDS) plots were constructed to project and interpret maternal biological relationships between the Mennonite communities and comparative populations in reduced dimensional space (Kruskal 1964). The genetic distance used in this analysis was a $d_{X Y}$ measure with a Tamura and Nei (1993) model of substitution and a $\gamma$ value of 0.26 (Meyer et al. 1999) computed in Arlequin 3.11. The Tamura and Nei distance corrects the percentage of nucleotides by which two base pairs differ and takes into consideration different mutation rates for transitions and transversions by making a distinction between purine and pyrimidine transition rates. The $\gamma$ value of Meyer et al. (1999) corrects for mutation rate heterogeneity in the mtDNA HVS-I region and allows for a less biased estimate of genetic diversity and population history parameters.

The MDS scores were computed and plotted using NTSYS (Applied Biostatistics, Setauket, New York). Intermatch distributions were calculated with the computer program IWAVE to determine potential population divergence between Mennonite communities (Sherry et al. 1994). Intermatch distributions compare the number of pairwise differences between randomly drawn individuals from two different populations (A. R. Rogers and Jorde 1995). Waves produced by intermatch distributions represent one of two events: (1) an expansion that occurred before the separation of an ancestral population, resulting in overlapping mismatch and intermatch distributions; or (2) a scenario in which the intermatch wave precedes the mismatch wave, which indicates that the population was subdivided before expansion with weak gene flow between subdivisions (A. R. Rogers and Jorde 1995).

Population Structure. To determine whether population structure could be detected between the six Mennonite communities, we applied a spatial analysis of molecular variance (SAMOVA) to identify partitions of population groupings based on HVS-I sequence using the computer program SAMOVA 1.0 (Dupanloup 
et al. 2002). This analytical method is based on a simulated annealing procedure and maximizes the proportion of total genetic variance resulting from differences between groups of populations $\left(F_{C T}\right)$. The final number of groups $(K)$ is based on the largest amount of variation shown by the $F_{C T}$ value that remains statistically significant. In contrast to other measures of genetic structure in which groups are defined a priori based on geographic, linguistic, or ecological factors, SAMOVA determines group classification solely on genetic information (Nasidze et al. 2004). Analyses were based on 100 annealing steps and examined maximum indicators of differentiation ( $F_{C T}$ values) when the program was instructed to categorize $K=2$ to $K=6$ partitions of population groupings.

\section{Results}

Haplogroup Distribution. RFLP analysis revealed that the six studied Mennonite communities are characterized by differing frequencies in eight $(\mathrm{H}, \mathrm{HV} 0$, $\mathrm{I}, \mathrm{J}, \mathrm{K}, \mathrm{T}, \mathrm{U}$, and $\mathrm{X}$ ) of the sixteen mtDNA haplogroups detected in the comparative populations (Table 1). The eight haplogroups not found in these Mennonite populations were $\mathrm{B}, \mathrm{D}, \mathrm{HV}, \mathrm{N}, \mathrm{R}, \mathrm{V}, \mathrm{W}$, and $\mathrm{Z}$. However, with the exception of haplogroup $\mathrm{V}$, these haplogroups are rare and have been detected in only a small subset of European groups and in a small number of individuals. In addition, other comparative Anabaptist groups also lack these haplogroups.

The most common haplogroup, $\mathrm{H}$, was found in all six study communities and in all comparative populations. This haplogroup was highest in Meridian (78\%) and lowest in Henderson (37\%). Haplogroup U (12\%) was the only other haplogroup detected in all six Mennonite groups and was also found in all other comparative populations except the Hutterites. The frequency of this haplogroup ranged from $26 \%$ in Henderson to $4 \%$ in Goessel. Haplogroups $\mathrm{T}(9 \%)$ and $\mathrm{J}$ (8\%) were the next most common mtDNA variants and were each found in four communities. Haplogroup $J$ was highest in Meridian (17\%) and lowest in Old Order Mennonites (6\%). Haplogroup HV0 was identified only in the Henderson community (6\%). Similar to other Anabaptist populations, the Mennonites are characterized by a reduced number of haplogroups compared to their related European populations. The Mennonites are characterized by higher frequencies of haplogroup $\mathrm{H}$, Hutterites are characterized by higher frequencies of $\mathrm{X}$, and the Amish are characterized by higher frequencies of haplogroup $T$ than their suggested founding populations.

HVS-I Sequencing. Mitochondrial DNA HVS-I sequencing results for 118 Mennonite participants are presented in Table 2. Based on diagnostic control region mutations, these sequences belong to mtDNA haplogroups $\mathrm{H}(n=71), \mathrm{HV0}$ $(n=1), \mathrm{I}(n=6), \mathrm{J}(n=9), \mathrm{K}(n=2), \mathrm{T}(n=11), \mathrm{U}(n=14)$, and $\mathrm{X}(n=3)$. Fiftyeight different mtDNA haplotypes characterized by 43 different nucleotide variants were observed compared to the Cambridge Reference Sequence (Anderson et al. 1981; Andrews et al. 1999). 
274 / MELTON ET AL.

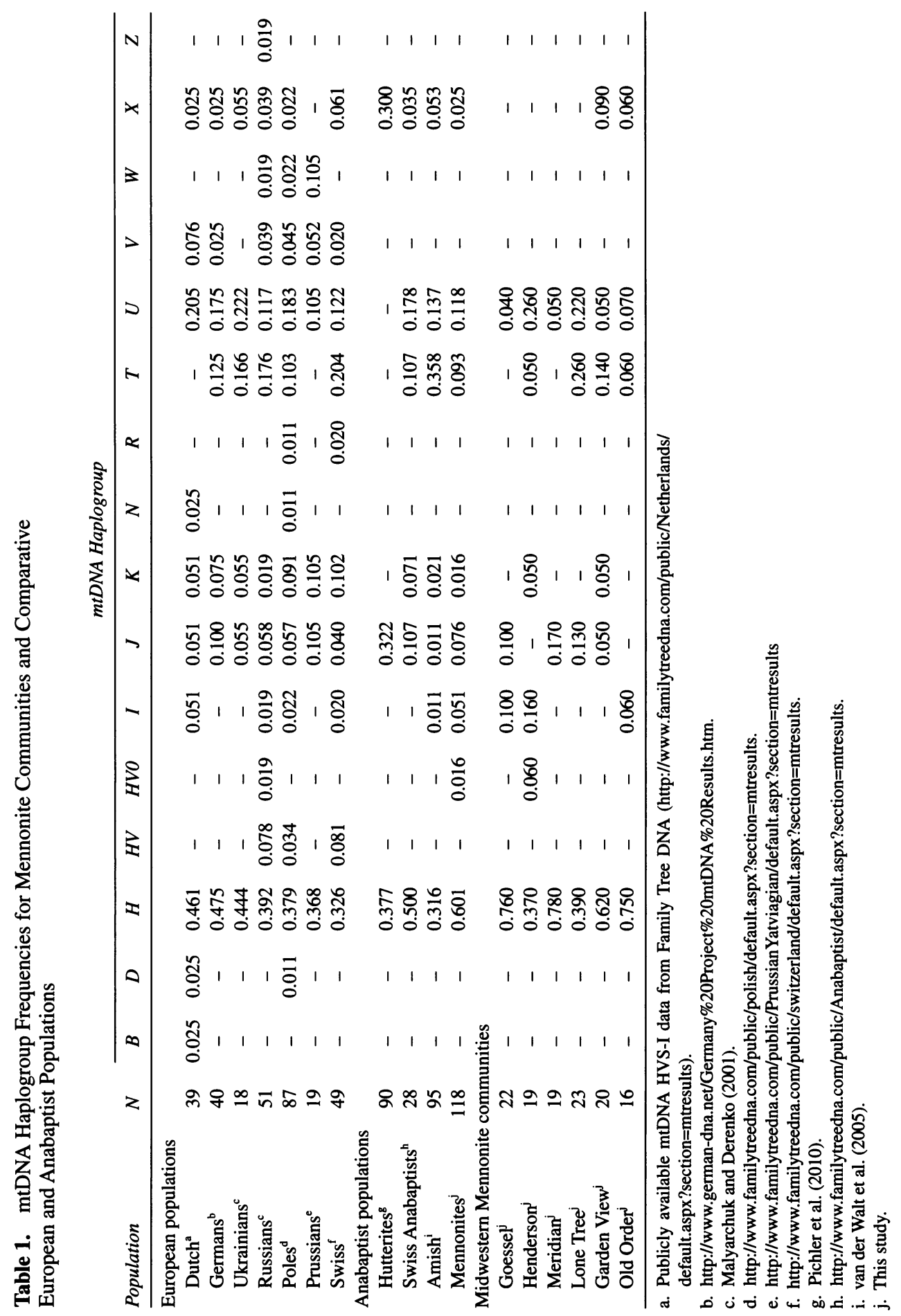


mtDNA Diversity in Midwestern Mennonites / 275

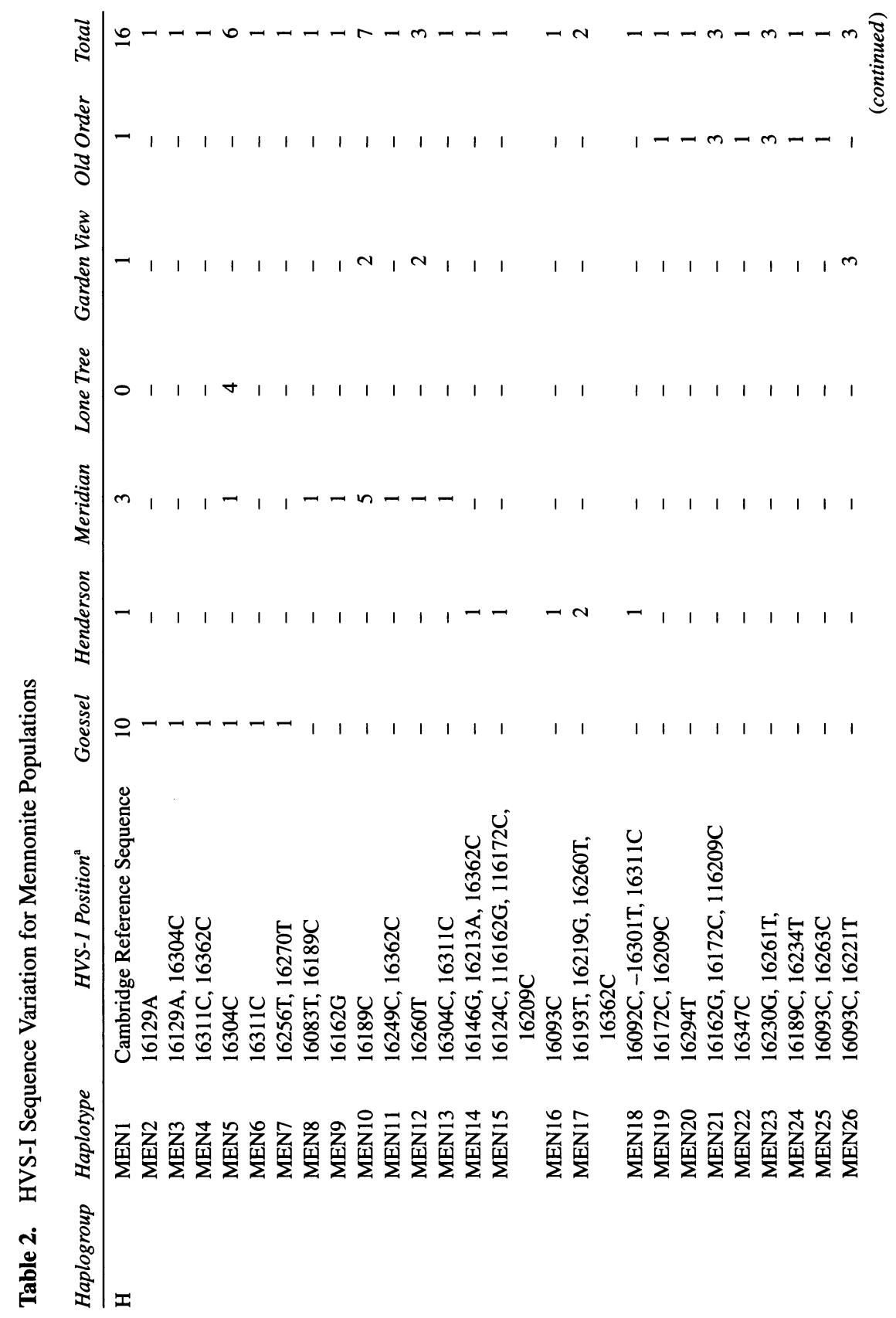


276 / MELTON ET AL.

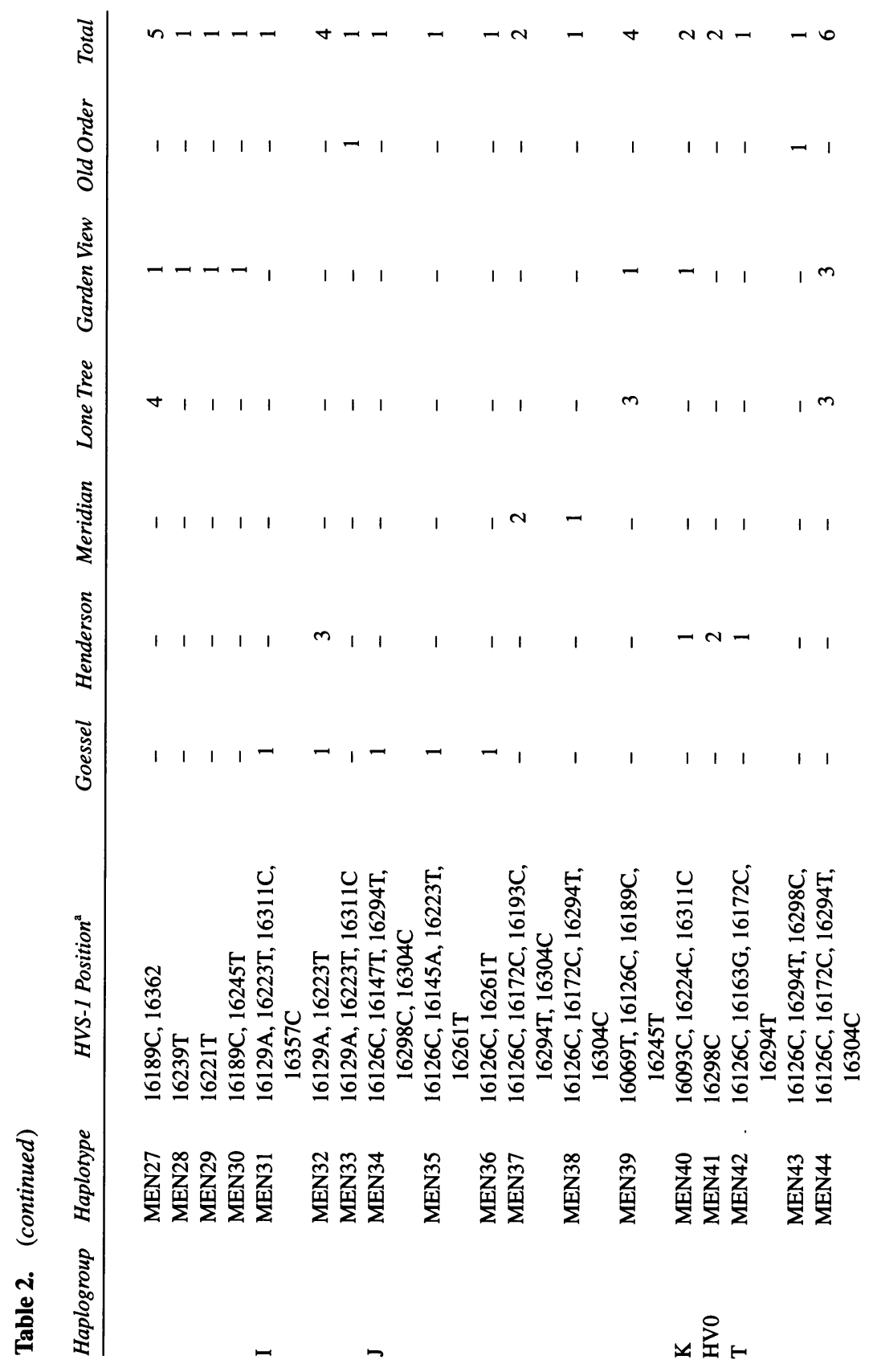




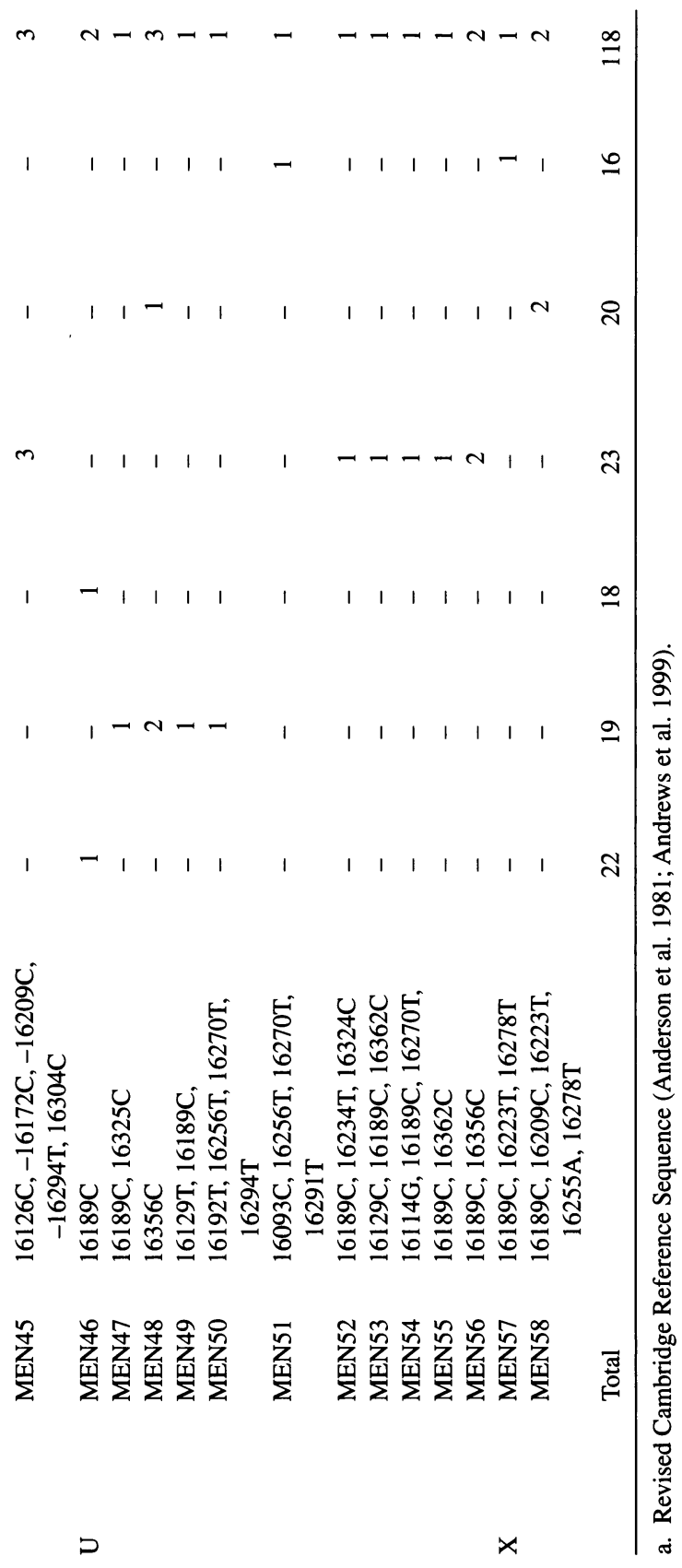


Haplogroup $\mathrm{H}$ demonstrated the most variation and contained 30 haplotypes. Eleven lineages belonged to haplogroup $\mathrm{U}$, six lineages to haplogroup J, four haplotypes to T, three haplotypes to I, and two to X. Both haplogroups HVO and $\mathrm{K}$ were represented by a single haplotype. Thirty-eight haplotypes are singletons because they were detected in single individuals. The remaining twenty haplotypes were shared between two or more participants.

The only haplotype (MEN1) shared by participants from all six communities was the Cambridge Reference Sequence, which belongs to subclade H2a2 of haplogroup H. Only one other haplotype (MEN5) was shared by more than two communities. This haplotype was characterized by a $\mathrm{T} \rightarrow \mathrm{C}$ transition at np 16304 and was detected in Goessel, Meridian, and Lone Tree. Seven haplotypes (MEN10, MEN12, MEN27, MEN32, MEN39, MEN44, and MEN48) were shared between two of the six investigated cohorts. The remaining 49 haplotypes were identified in only a single community.

Table 3 summarizes diversity measures and neutrality test statistics for the six study communities and for the comparative European and Anabaptist populations. Among the six study groups, the Goessel cohort demonstrated the lowest haplotype diversity (0.81), whereas the highest magnitude of HVS-I variation was exhibited in Henderson (0.96) and Garden View (0.96). Evidence of high haplotype diversity $(>0.90)$ was also found in the Old Order and Lone Tree communities.

Nucleotide diversity levels ranged from a high of 0.016 in Henderson to a low of 0.005 in Goessel. These two populations were also the only Mennonite communities to exhibit significant negative Tajima's $D$ values, which may be indicative of population expansion. Two populations, Meridian and Lone Tree, did not demonstrate significant Fu's $F_{s}$ values, but the associated values were negative. This is suggestive of population expansion, but it is possible that the small number of haplotypes $(n=9)$ is responsible for this nonsignificant result. The Hutterites were the only comparative population to exhibit a positive nonsignificant $D$ value. In addition, they were the only group to demonstrate a positive $F_{s}$ value. These results are indicative of genetic drift affecting the Hutterites. All other comparative populations exhibited significant $D$ and $F_{s}$ values, signifying population expansion.

Mismatch distributions for all six study populations are shown in Figure 2. Five of the distributions are multimodal and ragged (Harpending's raggedness index ranged from 0.42 in Lone Tree to 0.78 in Garden View). Only the Old Order congregation demonstrates a unimodal mismatch distribution. The other five distributions are also not identical to one another. Goessel has peaks at $i=3$ and 5, Meridian at 2 and 7, Henderson at 4 and 6, Garden View at 4 and 6, and Lone Tree at 4 and 7. This multimodal and ragged distribution is suggestive of differential bottlenecks and founder effects that have affected these groups since they split from their European founding populations.

Phylogenetic Analysis. A median-joining network for all six investigated Mennonite communities is displayed in Figure 3 and is based on HVS-I sequences 
Table 3. Descriptive and Neutrality Test Statistics for HVS-I Haplotypes

\begin{tabular}{lcccccc} 
Population & $N$ & $\begin{array}{c}\text { Number of } \\
\text { Haplotypes }\end{array}$ & $\begin{array}{c}\text { Haplotype } \\
\text { Diversity } h(S D)\end{array}$ & $\begin{array}{c}\text { Nucleotide } \\
\text { Diversity } \pi\end{array}$ & Tajima's D & Fu's $F_{s}$ \\
\hline Goessel $^{\mathrm{a}}$ & 22 & 13 & $0.81(0.09)$ & 0.005 & $-1.60^{*}$ & $-7.88^{* *}$ \\
Henderson $^{\mathrm{a}}$ & 19 & 14 & $0.96(0.02)$ & 0.016 & $-1.70^{*}$ & $-6.37^{* *}$ \\
Meridian $^{\mathrm{a}}$ & 18 & 9 & $0.86(0.06)$ & 0.006 & -0.76 & -2.39 \\
Garden View $^{\mathrm{a}}$ & 20 & 14 & $0.96(0.03)$ & 0.009 & -1.08 & $-6.06^{* *}$ \\
Lone Tree $^{\mathrm{a}}$ & 23 & 9 & $0.91(0.02)$ & 0.010 & 0.01 & -0.31 \\
Old Order $^{\mathrm{a}}$ & 16 & 13 & $0.97(0.04)$ & 0.010 & -1.41 & $-6.93^{* *}$ \\
Hutterites $^{\mathrm{b}}$ & 90 & 11 & $0.83(0.02)$ & 0.015 & 0.83 & 3.75 \\
Swiss Anabaptists $^{\mathrm{c}}$ & 28 & 23 & $0.98(0.01)$ & 0.013 & $-1.80^{*}$ & $-16.92^{* *}$ \\
Dutch $^{\mathrm{d}}$ & 39 & 30 & $0.98(0.01)$ & 0.011 & $-1.97^{* *}$ & $-24.95^{* *}$ \\
Germans $^{\mathrm{e}}$ & 40 & 26 & $0.91(0.03)$ & 0.009 & $-1.64 *$ & $-18.36^{* *}$ \\
Ukrainians $^{\mathrm{f}}$ & 18 & 16 & $0.98(0.02)$ & 0.012 & $-1.55^{*}$ & $-10.51^{* *}$ \\
Russians $^{\mathrm{f}}$ & 51 & 43 & $0.98(0.01)$ & 0.011 & $-1.92^{* *}$ & $-25.74^{* *}$ \\
Poles $^{\mathrm{g}}$ & 87 & 57 & $0.97(0.01)$ & 0.011 & $-2.06^{* *}$ & $-25.71^{* *}$ \\
Prussians $^{\mathrm{h}}$ & 19 & 17 & $0.98(0.02)$ & 0.013 & $-1.73^{*}$ & $-10.93^{* *}$ \\
Swiss $^{\mathrm{i}}$ & 47 & 34 & $0.98(0.01)$ & 0.012 & $-1.86^{*}$ & $-25.48^{* *}$ \\
\hline
\end{tabular}

$* p<0.05$.

$* * p<0.01$.

a. This study.

b. Pichler et al. (2010).

c. Publicly available mtDNA HVS-I data from Family Tree DNA (http://www.familytreedna.com/ public/Anabaptist/default.aspx?section=mtresults).

d. http://www.familytreedna.com/public/Netherlands/default.aspx?section=mtresults.

e. http://www.german-dna.net/Germany\%20Project\%20mtDNA\%20Results.htm.

f. Malyarchuk and Derenko (2001).

g. http://www.familytreedna.com/public/polish/default.aspx?section=mtresults.

h. http://www.familytreedna.com/public/PrussianYatviagian/default.aspx ?section=mtresults.

i. http://www.familytreedna.com/public/switzerland/default.aspx ?section=mtresults.

from 118 participants. This graph is rooted on the L3a haplogroup and is based on the current mtDNA phylogeny (van Oven and Kayser 2009). Of the 58 haplotypes detected in this analysis, only 12 are shared between the six study communities. Haplogroup $\mathrm{H}$ displayed a starlike pattern and demonstrated the most genetic variation, with 30 haplotypes. For this analysis, haplogroup $\mathrm{H}$ was centered on the Cambridge Reference Sequence and is characterized by several reticulations because of a number of shared nucleotide variants between haplotypes. This result is similar to several other studies of haplogroup $\mathrm{H}$ in European populations in which a number of homoplasies in HVS-I have been shown to be present. A starlike phylogeny is also apparent for haplogroup $U$, which can be further subdivided into three daughter haplogroups: (1) U4, defined by a $\mathrm{T} \rightarrow \mathrm{C}$ transition at HVS-I position 16356; (2) U5, characterized by the $\mathrm{C} \rightarrow \mathrm{T}$ transition at np 16270; and (3) $\mathrm{K}$, defined by the presence of the $16311 \mathrm{~T} \rightarrow \mathrm{C}$ and $16224 \mathrm{~T} \rightarrow \mathrm{C}$ transitions. The remaining haplogroups $(\mathrm{J}, \mathrm{T}, \mathrm{I}$, and $\mathrm{X}$ ) visible in this study did not have sufficiently high resolution to subdivide them into mtDNA subclades. 


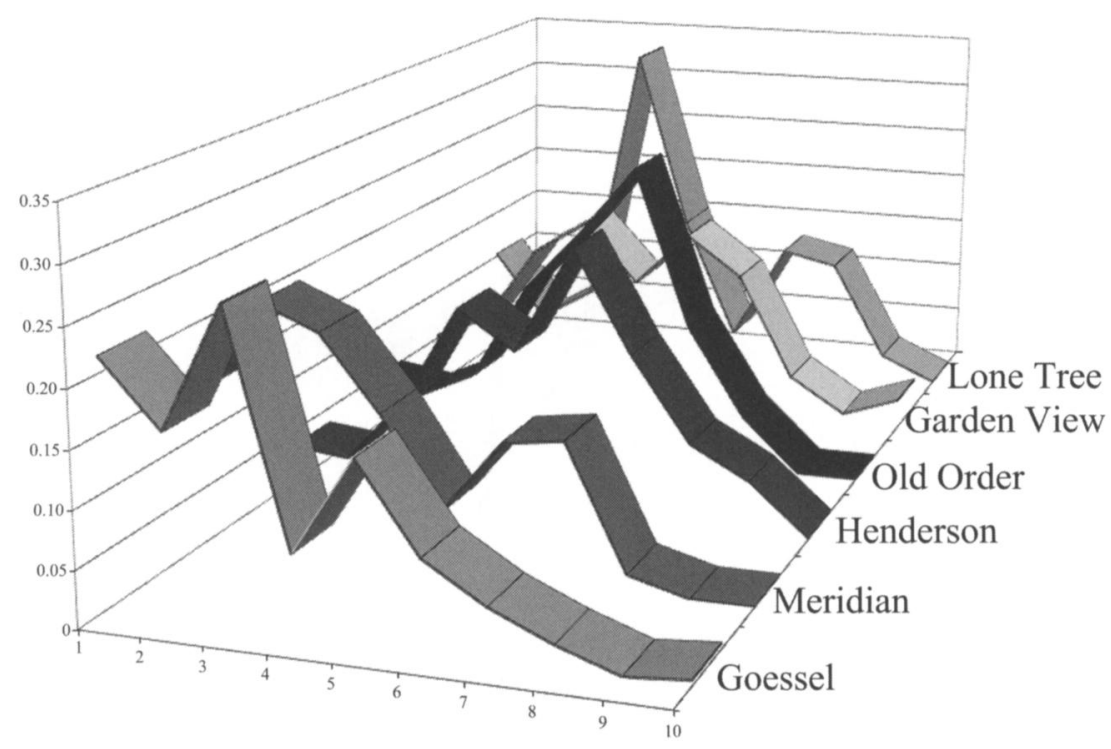

Figure 2. Mismatch distributions of the six study communities (Goessel, Meridian, Henderson, Old Order, Garden View, and Lone Tree). Number of nucleotide differences are indicated along the $x$ axis, and the frequency of pairwise differences are indicated along the $y$ axis.

Two MDS plots were constructed for this study using HVS-I sequence data from the six study populations and from European and Anabaptist comparative populations. Figure 4 shows the MDS plot of six Mennonite communities (stress $=0.02$, goodness of fit $=0.98$ ). This plot separates Mennonite communities into four groups distinguished by their associated congregation. The first cluster includes Goessel and Henderson, which belong to the Alexanderwohl congregation; the second cluster includes Meridian and Garden View, which are closely associated with each other in the Halderman congregation. Lone Tree is also included in this congregation, but there is a significant genetic distance between this community and the other two populations. The third congregation consists solely of the Old Order Mennonites and is isolated from both the Alexanderwohl and Halderman groups.

The second MDS plot compares European and Anabaptist populations to three Mennonite congregations (Alexanderwohl, Halderman, and Old Order) (Figure 5). This plot had a low stress value (0.002) and a high goodness of fit (0.95). The Hutterites (not shown) were clearly an outlier in this plot, which is similar to results from a recent paper comparing them to other European populations (Pichler et al. 2010). The Halderman and Old Order Mennonite congregations appear to be distinct from the other comparative European populations, 


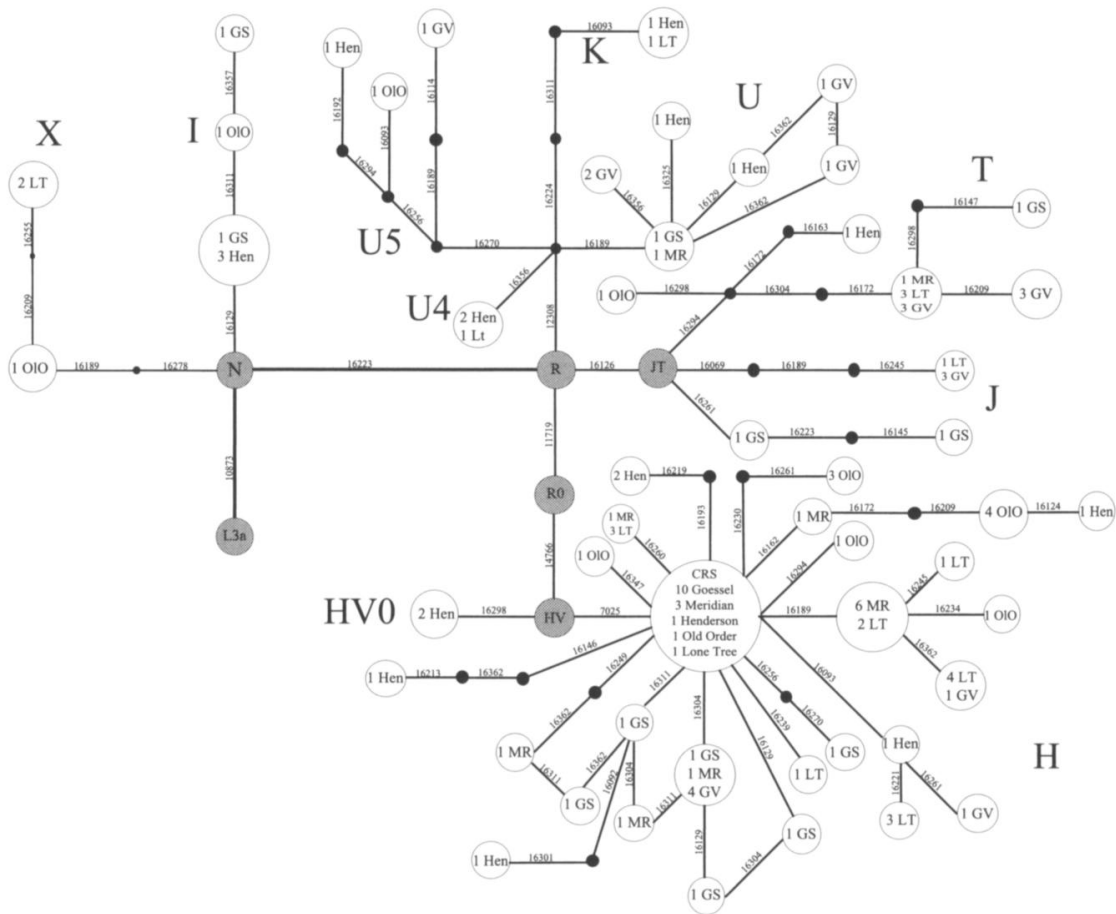

Figure 3. Median-joining network of mtDNA HVS-I sequences in six Mennonite communities. The network is rooted on haplogroup L3a and is based on the current human mtDNA phylogenetic tree (van Oven and Kayser 2009). Individual nodes represent haplotypes, and lines represent mutational pathways. Numbers are indicative of mutations within the mtDNA HVS-I region (16000-16400) and diagnostic coding region sites $(10873,11719,14766$, 7025). GS, Goessel; MR, Meridian; Hen, Henderson; LT, Lone Tree; Olo, Old Order; GV, Garden View.

whereas Alexanderwohl is closest to the Dutch, their ancestral population. Swiss Anabaptists appear to be the most European of the Anabaptists and are closest to the Swiss and German populations.

Intermatch distributions were calculated between the three Mennonite congregations (Alexanderwohl, Halderman, and Old Order) and are exhibited in Figure 6 along with mismatch distributions for each community. Both of these distributions were unimodal for all three groups. Intermatch distributions for all three congregations overlap and indicate a shared genetic history for all Mennonite communities. The least ragged of these distributions was between Alexanderwohl and Halderman, which is indicative of their more recent shared history. This is also demonstrated by the overlap in the intermatch distances between these two groups and Old Order Mennonites, indicating similar genetic histories for both. However, it is important to remember that coalescent events are more useful at elucidating early demographic events. Therefore these results are more indicative 


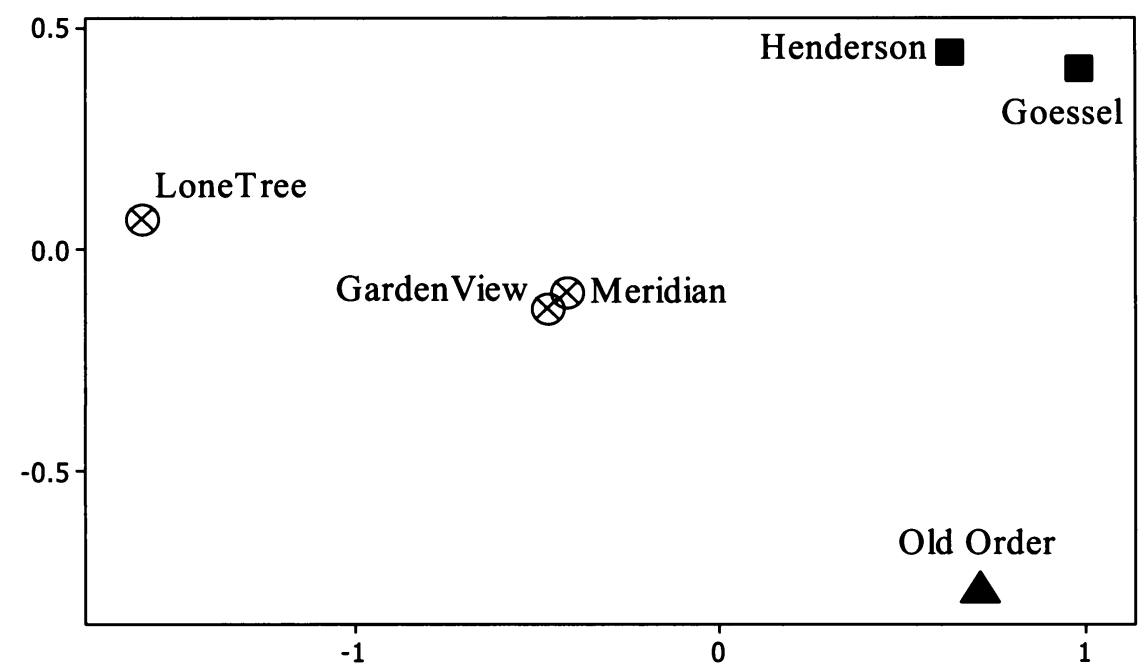

Figure 4. Multidimensional-scaling plot of six Mennonite communities aggregated by their associated congregation. Stress value $=0.02$; goodness of fit $=0.98$.

of the origin of ancestral maternal European populations and may be shared with other continental populations.

Population Structure. A SAMOVA was run for $K$ (number of groups) equal to 2 to 6 to establish whether populations in the region could be grouped based on their geographic location. The most parsimonious SAMOVA was found for $K=4\left(F_{C T}=0.07, p=0.02\right)$, which demonstrated the highest percentage of variation explained among groups (7.10\%) and remained statistically significant. The four groupings determined by this analysis were (1) Goessel and Henderson, (2) Meridian and Garden View, (3) Lone Tree, and (4) Old Order. These results are supported by the MDS plot shown in Figure 4.

\section{Discussion}

Religious isolates have long been known to be informative for understanding the complex etiology of rare genetic disorders. However, few studies have focused on applying modern molecular genetic data to further understand the population structure and recent genetic history of Anabaptist religious populations. This study focused on the use of mtDNA to further elucidate the genetic history of the Mennonite population of the United States. Our results reveal that the Mennonites have a typical western Eurasian mtDNA haplogroup profile but that their HVS-I sequences differentiate the Old Order and Halderman congregations from their ancestral European populations. In addition, we find a shared 


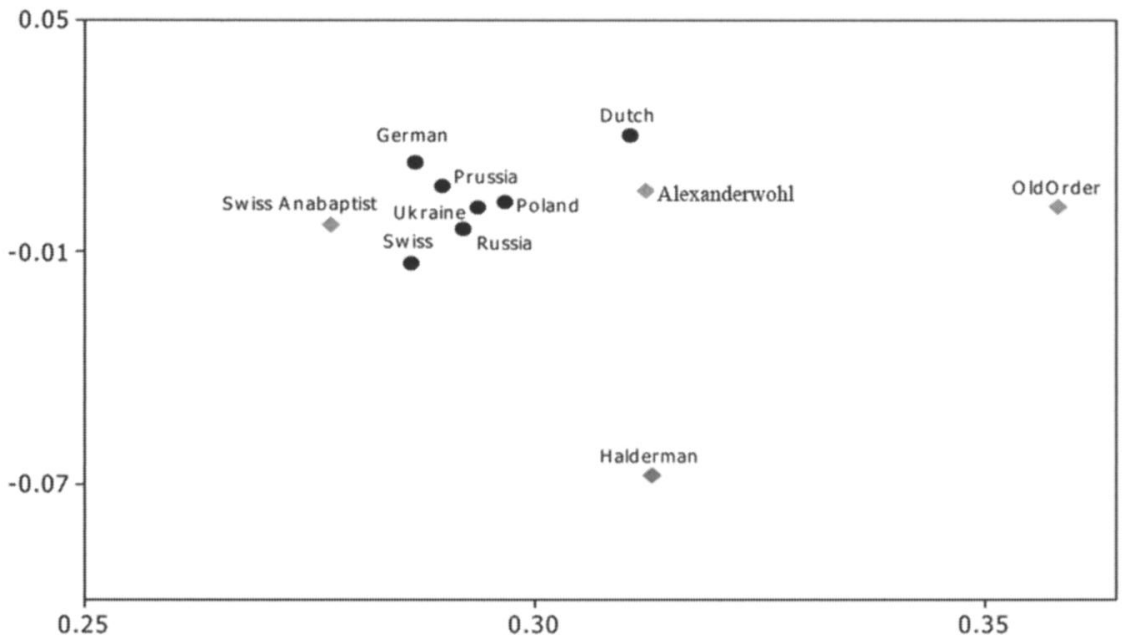

Figure 5. Multidimensional-scaling plot of three Anabaptist congregations (Alexanderwohl, Halderman, and Old Order) and comparative populations. Stress value $=0.002$; goodness of $\mathrm{fit}=$ 0.95 . Hutterites not shown (position on plot $x=-3.31504, y=0.0327286$ ).

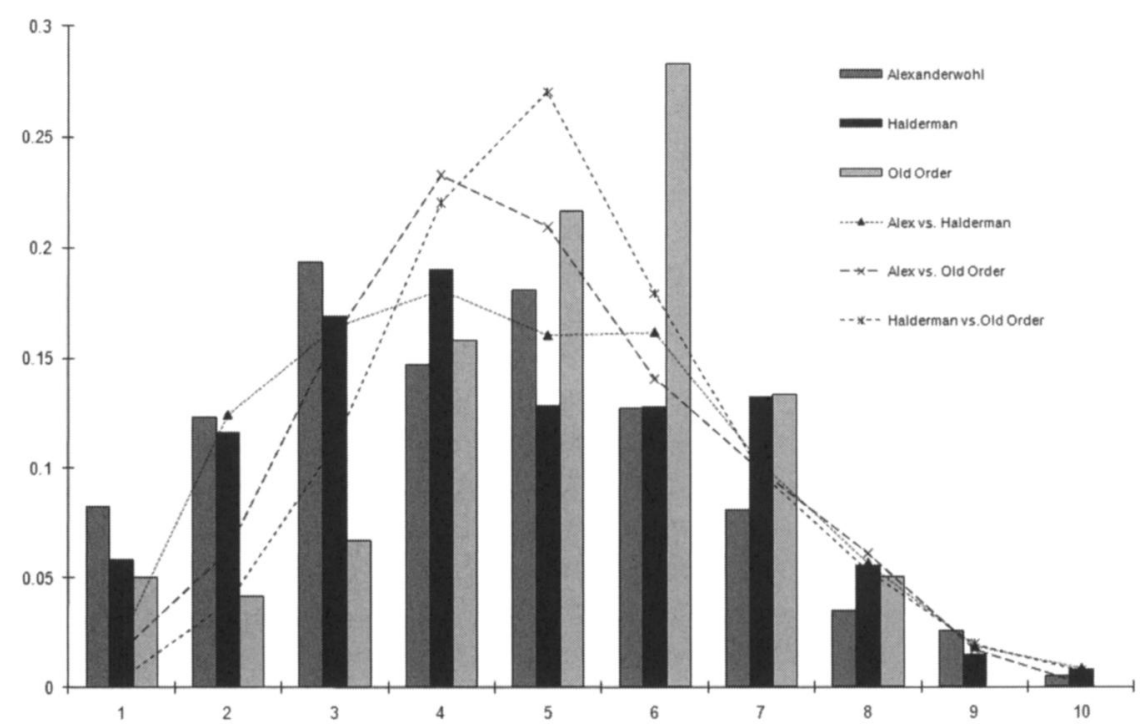

Figure 6. Mismatch (bars) and intermatch (lines) distributions between three Mennonite congregations: (1) Alexanderwohl (Goessel and Henderson); (2) Halderman (Meridian, Lone Tree, Garden View); and (3) Old Order. 
maternal biological relationship between Mennonite communities that is delineated through the affiliation within the three investigated congregations. The resulting population subdivision of these communities into congregations supports previously published reports regarding known patterns of kin-structured fissionfusion and founder effect (Crawford 2000b; Crawford et al. 1989; Martin et al. 1996) and offers clarification of the relationship between genetic characteristics and demographic movement for these Mennonite groups.

Most Mennonite communities have high frequencies of mtDNA haplogroup $\mathrm{H}$ that they share with all the comparative European and Anabaptist populations used in this study. The Mennonites differ in having a higher frequency (60\%) of this haplogroup than other European or Anabaptist populations. The only European group with a higher frequency of haplogroup $\mathrm{H}$ is the Basque $(66 \%)(\mathrm{Be}-$ tranpetit et al. 1995; Côrte-Real et al. 1996). This result indicates that Mennonites are of European origin and that there has been little or no admixture with $\mathrm{Na}$ tive American, African, or Asian groups since their arrival in North America in the 1870s. The Mennonite gene pool was heterogeneous in origin, with converts coming from the Dutch, northern Germans, and Swiss populations. However, the Alexanderwohl congregation appears to be closest to their founding population in the Netherlands (see Figure 5). For the other two Mennonite (Halderman and Old Order) congregations subsequent events appear to have affected the population dynamics of these communities, distinguishing them from other European groups.

The Halderman and Old Order congregations are distinguished from their ancestral European populations based on HVS-I sequence data. The MDS plot (Figure 5) reveals that these two Mennonite groups appear isolated from other European populations. Only the Alexanderwohl congregation exhibits a relationship with the Dutch but not with other European populations. This group originated in the Netherlands and then inhabited Prussia and the Ukraine before immigrating to the Americas, but the members do not appear to have intermarried with these populations. This difference may be indicative of the religious persecution that Anabaptist groups experienced during the Reformation and the subsequent isolation that Mennonites faced as they migrated through Europe. These religious subdivisions occurred along familial lines, and these events have formed the current maternal genetic structure of these communities. This structure is demonstrative of religious isolation, as these populations preferred cultural insulation and maintained endogamous marriage patterns until recently. However, the history of Mennonite populations is more complex than reproductive isolation.

The high haplotype diversity demonstrated in some of the Mennonite communities cannot be the result of high levels of inbreeding. Since the 1930s, reproductive isolation in this group has declined markedly and marital migration from other Mennonite communities has been the primary source of gene flow into the midwestern Mennonite population (Crawford et al. 1989). The Mennonites from the Alexanderwohl community experienced high inbreeding $(F=0.0162)$ in the 19th century while residing in Przechówko, Prussia (L. Rogers 1984), which would indicate that they should maintain a genetic relationship with the Dutch but 
not with other European populations, as apparent in the MDS plot (see Figure 5). After relocation to the Midwest, the inbreeding coefficient declined from 0.02 to 0.0062 . The effects of inbreeding have been swamped during the last two generations as the majority of young Mennonites attending colleges in Tabor Goessel have found mates from other Mennonite communities. Thus the genetic structure of the Mennonite communities in Kansas and Nebraska has been affected by fusion, fission, inbreeding, and exogamy (Crawford 2000c). This does not explain the high amount of mtDNA haplotype diversity observed in Old Order Mennonites, the only congregation that still inhabits a close-knit colony with little interaction with outside populations. However, this result may be explained by the relatively small sample size used in this group or by the fact that this group is a portion of a large Mennonite colony inhabiting northern Mexico.

The study of the population structure of Kansas and Nebraska Mennonite mtDNA variation is also useful for reconstructing the recent evolutionary history of these communities. The two communities representing the Alexanderwohl congregation, Goessel and Henderson, are the descendants of 191 immigrant families from the Molotschna Mennonite Colony in the Ukraine. Shortly after arrival in Kansas, these families underwent further fission because of doctrinal differences, thus creating the two present-day congregations. The rapidly growing Halderman congregation is a composite of Molotschna Mennonites, Pennsylvania Dutch, and local converts, and this is demonstrated by considerable variation being present in these populations. Yet within these communities the congregations that fissioned from their parental churches are clearly distinguishable from one another, despite their recent separation.

The MDS plot (Figure 4) of Mennonite communities is indicative of the evolutionary pattern of fission-fusion that these populations have undergone since originating in Europe during the Reformation. The MDS plot clearly segregates out the Alexanderwohl congregation from both the Halderman and Old Order congregations. This result differs somewhat from previous research involving classical genetic markers. Crawford (2000b), using 25 alleles from classical genetic loci, found a closer than expected phylogenetic relationship between Henderson and Meridian. Similarly, Martin et al. (1996) and Demarchi et al. (2005) found a closer genetic relationship between Meridian and Henderson using immunoglobulin and apolipoprotein data, respectively. These mtDNA data show a close evolutionary relationship between Henderson and Goessel, but these populations share few haplotypes, indicating that after their arrival in the Midwest, the Alexanderwohl congregation split into two groups along familial lines. Because mtDNA records only the maternal side of genetic history, it is possible that these data reflect a cultural practice in which females remained within the traditional congregation while males moved between them. Thus, in order for this hypothesis to be confirmed, data from the Y chromosome in these communities are needed.

The Halderman Mennonite congregation shows considerable genetic variation, despite its recent history. This result indicates kin-based fission within this 
group. Historically, Garden View and Lone Tree split from Meridian recently and are considered more traditional than the Alexanderwohl congregation. Apolipoprotein data suggest a closer genetic relationship between Goessel and Garden View and between Meridian and Henderson with Lone Tree as an outlier (Demarchi et al. 2005). Once again the MDS plot (Figure 4) and SAMOVA results show Lone Tree to be an outlier but closer to Meridian and Garden View, suggesting that this population is distinct from the other two Halderman congregations. However, based on shared mtDNA haplotypes, there is a closer maternal genetic relationship between these Halderman communities and this relationship is best explained though kinship-structured migrations. The evolutionary consequence of this practice is that genetic variation will increase with its greatest effect being in small populations (Fix 2004).

The Old Order Mennonite congregation is the most distinct of the communities analyzed during this research, and this is reflective of their unique evolutionary history. This community first emigrated from Alberta, Canada, to Chihuahua, Mexico, in the 1920s. Then, beginning in the late 1990s, Old Order Mennonites began to immigrate to southwestern Kansas to escape the ongoing drug violence along the U.S.-Mexican border. During their time in Mexico, this group apparently remained isolated from outside admixture with either the Mestizo of Chihuahua or the indigenous Tarahumara populations. This pattern of endogamy is reflected in their genetics, as none of the four major Native American mtDNA haplogroups (A2, B2, C1, or D1) are present in this group. A single Old Order individual is characterized by haplogroup $\mathrm{X}$, which is known to occur in southwestern Native American groups and has been reported in the Tarahumara (Peñaloza-Espinosa et al. 2007). However, based on the current HVS-I evidence, we are unable to determine whether this finding represents Native American or a Eurasian X component. The two haplogroup X individuals identified in Garden View belong to the $\mathrm{X} 2$ subhaplogroup X2c, based on the $16255 \mathrm{~A}$ transition (Perego et al. 2009; Reidla et al. 2003); this subhaplogroup is also exhibited by the Hutterite population (Pichler et al. 2010).

\section{Conclusion}

Mitochondrial DNA variation within these Mennonite communities is consistent with a population that originated in western Europe and migrated to North America. Previous research using classical genetic data has shown a genetic relationship between disparate Mennonite groups with different evolutionary histories, but this study accurately reflects the known histories of these communities. This better fit between history and genetics is probably due to the higher resolution that molecular data can provide, reflecting the differences between migration patterns between males and females in Mennonite communities. Given the short time frame involved in the origin and differentiation of Mennonite populations, these results clearly illustrate the effects of microevolution on small human populations. 
Acknowledgments We thank two anonymous reviewers for their useful comments regarding this manuscript. We also thank the Mennonite communities of Kansas and Nebraska for their participation in this project. This research was sponsored by the National Institute of Aging through grant AGO1646 and by a Kansas Attorney General Settlement Grant (KUCR KAN 30471).

Received 3 June 2009; revision accepted for publication 15 February 2010.

\section{Literature Cited}

Achilli, A., U. A. Perego, C. M. Bravi et al. 2008. The phylogeny of the four Pan-American mtDNA haplogroups: Implications for evolutionary and disease studies. PLoS One 3(3):e1764.

Allen, G. 1988. Random genetic drift inferred from surnames in Old Colony Mennonites. Hum. Genet. 60:639-653.

Allen, G., and C. W. Redekop. 1967. Individual differences in survival and reproduction among Old Colony Mennonites in Mexico: Progress to October 1966. Eugen Q. 14:103-111.

Allen, G., and C. W. Redekop. 1987. Old Colony Mennonites in Mexico: Migration and inbreeding. Soc. Biol. 34(3-4):166-179.

Anderson, S., A. T. Bankier, B. G. Barrell et al. 1981. Sequence and organization of the human mitochondrial genome. Nature 290:457-465.

Andrews, R. M., I. Kubacka, P. F. Chinnery et al. 1999. Reanalysis and revision of the Cambridge Reference Sequence for human mitochondrial DNA. Nat Genet. 23:147.

Bandelt, H. J., P. Forster, and A. Rohl. 1999. Median-joining networks for inferring intraspecific phylogenies. Mol. Biol. Evol. 16:37-48.

Bandelt, H. J., P. Forster, B. C. Sykes et al. 1995. Mitochondrial portraits of human populations using median networks. Genetics 141:743-753.

Behar, D. M., R. Villems, H. Soodyall et al. 2008. The dawn of human matrilineal diversity. Am. J. Hum. Gen. 82(5):1130-1140.

Bertranpetit, J., J. Sala, F. Calafell et al. 1995. Human mitochondrial DNA variation and the origin of Basques. Ann. Hum. Genet. 59:63-81.

Caliskan, M., I. Pichler, C. Platzer et al. 2008. Y chromosome microsatellite haplotypes in the Hutterite founders. Am. Soc. Hum. Gen. Mtgs. Abstr., 477.

Côrte-Real, H. B. S. M., V. A. Macaulay, M. B. Richards et al. 1996. Genetic diversity in the Iberian peninsula determined from mitochondrial sequence analysis. Ann. Hum. Genet. 60:331-350.

Crawford, M. H., ed. 2000a. Different Seasons: Biological Aging Among the Mennonites of the Midwestern United States. University of Kansas Publications in Anthropology 21. Lawrence: Department of Anthropology, University of Kansas.

Crawford, M. H. 2000b. Genetic structure of Mennonite populations. In Different Seasons: Biological Aging Among the Mennonites of the Midwestern United States, M. H. Crawford, ed. University of Kansas Publications in Anthropology 21. Lawrence: Department of Anthropology, University of Kansas, 31-40.

Crawford, M. H. 2000c. Twenty years of research on Mennonite biological aging: Perspectives. In Different Seasons: Biological Aging Among the Mennonites of Midwestern United States, M. H. Crawford, ed. University of Kansas Publications in Anthropology 21. Lawrence: Department of Anthropology, University of Kansas, 165-170.

Crawford, M. H. 2005. Genetics of biological aging in Mennonites of midwestern United States. Przeglad Antropologiczny 68:3-18.

Crawford, M. H., D. D. Dykes, and H. F. Polesky. 1989. Genetic structure of Mennonite populations of Kansas and Nebraska. Hum. Biol. 61(4):493-514.

Demarchi, D., M. J. Mosher, and M. H. Crawford. 2005. Apolipoproteins (apoproteins) and LPL variation in Mennonite populations of Kansas and Nebraska. Am. J. Hum. Biol. 17:593-600. 


\section{$288 /$ MELTON ET AL.}

Dupanloup, I., S. Schneider, and L. Excoffier. 2002. A simulated annealing approach to define the genetic structure of populations. Mol. Ecol. 11(12):2571-2581.

Excoffier, L., G. Laval, and S. Schneider. 2005. Arlequin ver. 3.0: An integrated software package for population genetics data analysis. Evol. Bioinform. Online 1:47-50.

Finnilä, A., M. S. Lehtonen, and K. Majamaa. 2001. Phylogenetic network for European mtDNA. Am. J. Hum. Genet. 68:1475-1484.

Fix, A. G. 2004. Kin-structured migration: Causes and consequences. Am. J. Hum. Biol. 16(4):387394.

Fu, Y. X. 1997. Statistical tests of neutrality of mutations against population growth, hitchhiking, and background selection. Genetics 147:915-925.

Hall, T. 1999. BioEdit: A user-friendly biological sequence alignment editor and analysis program for Windows 95/98/NT. Nucleic Acids Symp. Ser. 41:95-98.

Herrnstadt, C., J. L. Elson, E. Fahy et al. 2002. Reduced-median-network analysis of complete mitochondrial DNA coding-region sequences for the major African, Asian, and European haplogroups. Am. J. Hum. Genet. 70:1152-1171.

Hudson, R. 1990. Gene genealogies and the coalescent process. Oxford Surv. Evol. Biol. 9:1-44.

Kruskal, J. 1964. Multidimensional scaling by optimizing goodness of fit to a nonmetric hypothesis. Psychometrika 29:1-27.

Macaulay, V., M. Richards, E. Hickey et al. 1999. The emerging tree of west Eurasian mtDNAs: A synthesis of control-region sequences and RFLPs. Am. J. Hum. Genet. 64:232-249.

MacCulloch, D. 2003. The Reformation: A History. London: Viking Penguin.

Malyarchuk, B. A., and M. V. Derenko. 2001. Mitochondrial DNA variability in Russians and Ukrainians: Implication to the origin of the Eastern Slavs. Ann. Hum. Genet. 65:65-78.

Martin, K., J. C. Stevenson, M. H. Crawford et al. 1996. Immunoglobin haplotype frequencies in Anabaptist population samples: Kansas and Nebraska Mennonites and Indiana Amish. Hum. Biol. 68(1):45-62.

Meyer, S., G. Weiss, and A. von Haeseler. 1999. Pattern of nucleotide substitution and rate heterogeneity in the hypervariable regions I and II of human mtDNA. Genetics 152:1103-1110.

Nasidze, I., D. Quinque, I. Dupanloup et al. 2004. Genetic evidence concerning the origins of South and North Ossetians. Ann. Hum. Genet. 68(6):588-599.

Nei, M. 1987. Molecular Evolutionary Genetics. New York: Columbia University Press.

Peñaloza-Espinosa, R. I., D. Arenas-Aranda, R. M. Cerda-Flores et al. 2007. Characterization of mtDNA haplogroups in 14 Mexican indigenous populations. Hum. Biol. 79(3):313-320.

Perego, U. A., A. Achilli, N. Angerhofer et al. 2009. Distinctive Paleo-Indian migration routes from Beringia marked by two rare mtDNA haplogroups. Curr. Biol. 19:1-8.

Pichler, I., C. Fuchsberger, C. Platzer et al. 2010. Drawing the history of the Hutterite population on a genetic landscape: Inference from Y-chromosome and mtDNA genotypes. Eur. J. Hum. Genet. 18:463-470.

Ramos-Onsins, S. E., and J. Rozas. 2002. Statistical properties of new neutrality tests against population growth. Mol. Biol. Evol. 19:2092-2100.

Reidla, M., T. Kivisild, E. Metspalu et al. 2003. Origin and diffusion of mtDNA haplogroup X. Am. J. Hum. Genet. 73(5):1178-1190.

Rogers, A. R., A. E. Fraley, M. J. Bamshad et al. 1996. Mitochondrial mismatch analysis is insensitive to the mutational process. Mol. Biol. Evol. 13:895-902.

Rogers, A., and H. Harpending. 1992. Population growth makes waves in the distribution of pairwise genetic differences. Mol. Biol. Evol. 9:552-569.

Rogers, A. R., and L. B. Jorde. 1995. Genetic evidence on modern human origins. Hum. Biol. 67(1):136.

Rogers, L. 1984. Phylogenetic Identification of a Religious Isolate and the Measurement of Inbreeding. Ph.D. dissertation, University of Kansas, Lawrence.

Rogers, L., and R. A. Rogers. 2000. Mennonite history with special reference to Alexanderwohl and related congregations in Kansas and Nebraska. In Different Seasons: Biological Aging Among the Mennonites of the Midwestern United States, M. H. Crawford, ed. University of Kansas 
Publications in Anthropology 21. Lawrence: Department of Anthropology, University of Kansas, 7-18.

Saitou, N., and M. Nei. 1987. The neighbor-joining method: A new method for reconstructing phylogenetic trees. Mol. Biol. Evol. 4:406-425.

Sherry, S. T., A. R. Rogers, H. Harpending et al. 1994. Mismatch distributions of mtDNA reveal recent human population expansions. Hum. Biol. 66:761-775.

Stevenson, J., and P. Everson. 2000. Historical demography of Mennonite populations. In Different Seasons: Biological Aging Among the Mennonites of the Midwestern United States, M. H. Crawford, ed. University of Kansas Publications in Anthropology 21. Lawrence: Department of Anthropology, University of Kansas, 19-30.

Tajima, F. 1989. Statistical method for testing the neutral mutation hypothesis by DNA polymorphism. Genetics 123:585-595.

Tamura, K., and M. Nei. 1993. Estimation of the number of nucleotide substitutions in the control region of mitochondrial DNA in humans and chimpanzees. Mol. Biol. Evol. 10:512-526.

Torroni, A., K. Huoponen, P. Francalacci et al. 1996. Classification of European mtDNAs from an analysis of three European populations. Genetics 144:1835-1850.

Torroni, A., and D. C. Wallace. 1994. Mitochondrial DNA variation in human populations and implications for detection of mitochondrial DNA mutations of pathological significance. J. Bioenerg. Biomembr. 26:261-271.

van der Walt, J. M., W. K. Scott, S. Slifer et al. 2005. Maternal lineages and Alzheimer disease risk in the Old Order Amish. Hum Genet. 118(1):115-122.

van Oven, M., and M. Kayser. 2009. Updated comprehensive phylogenetic tree of global human mitochondrial DNA variation. Hum. Mutat. 30(2):E386-E394. Available at http://www.phylotree.org. 